\title{
Heterotopia and Illness: Older women and Hypertension in a Brazilian Favela
}

\author{
Annette Leibing, $\mathrm{PhD}$ \\ Professor of Medical Anthropology \\ Faculty of Nursing \\ Université de Montreal
}

\begin{abstract}
This article is about older women and the way hypertension is linked to their life in a favela, a "shantytown", in Rio de Janeiro. Inspired by Foucault, I suggest calling this complex phenomenon 'heterotopic illness'. By calling attention to the importance of place for understanding certain illnesses, the limited usefulness of some public health prevention campaigns is shown. Since hypertension can be considered a "disease of aging", it will be argued that some place-related stressors often have a greater impact on seniors than they have on younger adults.
\end{abstract}

Keywords: Heterotopic illness, favela, Brazil, place, hypertension, aging.

Mangueira*, your scenario is a beauty
That nature created, oh oh...
The hill with its huts made of zinc
How splendid it is in the early morning

(“Exaltação a Mangueira," Samba composed by Enéas B. Silva and Aloisio A. Costa, 1956; my translation)

* Mangueira is a well-known favela ('shantytown') in Rio de Janeiro

\section{M-16P. G-3. AK-47 \\ Uzi. Glock ${ }^{* *}$}

A missile is being fired (...)

To become stronger, to become stronger!
Mangueira teu cenário é uma beleza

Que a natureza criou ô ô...

O morro com seus barracões de zinco

Quando amanhecer que esplendor

(Forbidden funk music about violence in a favela; quoted in: Barcellos 2003: 29; my translation) $\quad{ }^{* *}$ names of weapons

Aging can be defined as the accumulation and embodiment of time, and the 'experienced body' of older individuals is spatially grounded in a number of ways. The link between certain spaces, sites or places ${ }^{1}$ with health or illness may be obvious: for example, a hospital can be a site of healing and yet also a site of contagion and illness when understaffed or infested with a bacteria such as clostridium difficile.

\author{
M-16P. G-3. AK-47 \\ Uzi. Glock \\ Fuzil lança rojão (...) \\ Pra fortalecê, pra fortalecê!
}

Other links between place, health and illness are more complex: Leon Eisenberg (2004), criticizing some forms of naive geneticism, states that, "nature and nurture stand in reciprocity, not opposition. Offspring inherit, along with their parents' genes, their parents, their peers and the places they inhabit" (Eisenberg 2004, 102; emphasis added). For older individuals, who experience more 
restrictions in their mobility, sensoriality (vision, hearing etc.), and decision-making capacities (e.g., dementias), a variety of public, private, virtual, and actual spaces play a role in impeding or enhancing citizenship, comfort and well being.

Spatial dimensions of illness are often treated as a variable - in public health studies for example whereby the willingness of individuals to maintain and achieve their health depends on their access to certain facilities such as gyms and public markets. Social scientists (such as Williams [1999] who writes about "therapeutic landscapes") often concentrate on the impact of domestic or institutional environments on older people's well being (e.g. Wiles et al. 2012). These discussions can be diversified by applying Michel Foucault's concept of "heterotopia" to certain illnesses and inquiring how illness and place are entangled on multiple levels, often configured by issues of identity and power.

Foucault outlines an analytical framework for discussing "counter-sites" in his short essays on heterotopia. ${ }^{2}$ Here, heterotopia refers to places that are exceptional to, or excluded from, mainstream society (cf. Foucault 2005, Sophia 2008, Elden 2001) or, "spaces of alternate social ordering" (Hetherington 1997). ${ }^{3}$ Foucault was strongly influenced by Georges Bataille, who originally developed the concept of heterotopia in the 1930s, describing it as a "science of the other", concerned about "the 'garbage' of society, its outlaws, ... mad laughter, the erotic, and violence" (see Chlada 2005, 13; translation mine). However, heterotopias are not conceived in opposition to mainstream society, rather site and counter-site are regarded as tightly interwoven in a very specific relationship:

But among all these sites, I am interested in certain ones that have the curious property of being in relation with all the other sites, but in such a way as to suspect, neutralize, or invent the set of relations that they happen to designate, mirror, or reflect. These spaces, ... are linked with all the others, ... however contradict all the other sites... ${ }^{4}$ (Foucault n.d.; emphasis added; see also Sohn 2008, 44-45)

A counter-site - or, otherness as a mirror - is not necessarily negatively related to mainstream society. However, when applying it to illness - an analytical choice that makes only sense when illness is embedded in a particular place - the counter-site can be described as mostly pathogenic (contaminated, polluted, stressful, violence-stricken for example).

This article is based on ethnographic research on elderly hypertensive women who live in a well-known favela in Rio de Janeiro. For these women, their association with the favela - a kind of shantytown - defines their worth and determines which type of interventions (social, medical etc.) can be claimed from governments, non-governmental organizations (NGOs) and other institutions. This kind of spatial citizenship is more often found in counter-sites heterotopias - because of the tensions that come with the "reverse side of society" (Sohn 2008).

Initially, I had intended to study dementia outside of the institutional settings of psychiatry and neurology (e.g., Leibing 2002, 2009). It was a surprise, then, that in the favela I had chosen, both patients and health professionals of the local health post deemed memory impairment, forgetfulness, senility and Alzheimer's disease as irrelevant to their reality. Instead, aging was firmly and repeatedly linked to hypertension, and the narratives about hypertension were embedded in the life in the favela. $^{5}$

In Rio de Janeiro, favelas are often located on a hill (as in the classic film Orfeu Negro [1959]), associated with a high crime rate (as in the well-known film City of God [2002]), but are also invested cultural heritage and considered as the site which originated popular music such as samba (see Barke, Escanasy and O'Hare 2001). A favela is an "imagined community" in a double sense - it is the troubling shadow of modern Brazil, evoking counter-narratives of the nation (cf. Bhabha 1994, 13ff.), but at the same time an idealized site of authentic Brazilianness and, therefore a mirror of society, as per Foucault's conceptualization of utopia (e.g. Chlada 2005; see also Leibing 2001 on the "good bandit").

During one year my colleague Daniel Groisman and I followed every week two groups of older women (and one man) who visited the health post - the posto, as everybody called it - located at the bottom of the hill. Due to the advanced age of the women we worked with (approximately 25 women aged 57-83 years), we had suggested meeting on the hill in order to facilitate their participation. The women, however, insisted that the 
health post was a safer place. But we also visited the homes of five of these women, who picked us up at the health post and carefully guided us into the favela, passing by the unofficial security people posted at the entrance, and through the meandering streets, paths, and staircases leading up the hill. In addition to the group meetings and the home visits, we conducted 10 individual interviews with group members, and five interviews, as well as regular informal chats, with the health professionals.

During the course of our fieldwork, we worked with two groups - each one for two hours every week. Different health professionals led the official "hypertension group," and we were allowed to pose some questions towards the end of each session. We led the second group, called the "memory group", because at the onset of our fieldwork, since dementia was not an issue, we were hoping to get at least some information on the concept of memory. This second group consisted of sessions based on themes preselected by members (some of the topics we discussed included: the favela versus the non-favela, women's everyday preoccupations and their life histories). This group was also made up of patients suffering from hypertension.

\section{THE FAVELA, THE NON-FAVELA AND THE HEALTH POST IN-BETWEEN}

Not all low-income communities in urban Brazil can be called favelas. This term generally refers to areas with illegal housing and is associated with a high prevalence of violence. Favelas emerged at the end of the 19th century as places of residence for newly-liberated slaves. Later they became the home for many migrants looking for work and a better life: An important period for the formation and expansion of favelas were the 1940s when, during the government of president Getúlio Vargas, people migrated to the Capital Rio de Janeiro and built their houses on the less valorized hills of the city. In the 1970s, another shift occurred when rural workers en masse moved into the big urban centers, most notably São Paulo and Rio de Janeiro, the two cities where by far the highest numbers of favelas exist (see for a more detailed analysis Valladares 2000, 2005, 2006; Valladares and Medeiros 2003; Zaluar and Alvito 2005, and many others).
Many Brazilians and foreigners consider favelas as dangerous areas associated with crime and illegality. Because of the high rates of violence in many favelas, constant distress impacts on health and well being of its inhabitants (cf. Epstein 2003; see also Duarte 1986). Life expectancy at birth can vary in Rio de Janeiro from 64.01 years in the poorer neighbourhoods to 73.25 years in the wealthier parts of the city (Sczwarszwald et al. 2000). However, a key factor responsible for the lower life expectancy in the favelas lies in the high rate of violent death among young men (Rocha 1998, Huguet and Szabo de Carvalho 2008). ${ }^{6}$

Not all favelas are violent and dangerous, but this reputation persists despite the attempts by nongovernmental organizations (NGOs) and the State to alter that image (e.g. through the current pacification measures [see Schiller 2013], favela tourism [e.g. Hanrahan 2013]) and, indirectly, by turning illegal housing into a legal one (such as the huge slum-to-neighborhood initiative Favela Bairro; see RioOnWatch 2010). Cidade de Deus (City of God), for instance - well known from the movie with the same name by Fernando Meirelles (2002) - should not be called a favela, because it is a government housing project. However, this part of Rio de Janeiro is called a favela due to its high rate of crime. This misrepresentation is a vivid example illustrating that 'favela' is less a geographic notion, but first of all a strong moral and stigmatizing term.

Foucault describes a heterotopia to be a space of deviation, with ever-shifting points of reference. A widely discussed book in Brazil entitled Cidade Partida (The Divided City) argues that "[ $t$ ]he City has been civilized and modernized by expelling its second class citizens to the hills and the periphery. The result of this kind of politics was a divided city... the choice was always the separation, or even a simple segregation" (Ventura 1994, 13). This description creates the illusion of a solid and unchallenged boundary between two discrete spaces, contrasting a modern city with a lawless periphery. More recent authors (e.g. Zaluar and Alvito 2005) point out that the notion of a divided city - the favela versus nonfavela - is too simple for a complex metropolis like Rio de Janeiro. ${ }^{7}$ Rather than two distinctly separate spaces, the favela and the 'asphalt' (asfalto) - as the non-favela is often 
called - are linked by everyday practices in a globalized world, constantly creating connections and reinforcing boundaries (cf. Segre 2008, Porto 2000). As an example, during our fieldwork, we encountered women from the favela who had little formal education and very limited means who adopted a "successful aging" discourse and other key psychological concepts in the same manner as the women of a similar age, living outside of the favela. The social workers, doctors, and psychologists at the health post, along with the world of television, were responsible for transmitting a notion of self that needed to be active and in need of a double improvement: Through the working of self esteem being old and poor should become less disabling, mingling social, psychological and physiological factors contributing to hypertension, some of which will be discussed more in the section on 'risk talk'.

A favelado is often seen as a marginalized person and a favela is what Bachelard (1994) called a 'hostile space'. But this is only one part of the picture - a number of associations are positive, such as the roots of popular culture found in the samba singers, the queens and kings of carnival, and a notion of community-based life versus the individualized life generally associated with the big urban centers. ${ }^{8}$ Many women expressed their preference for the favela (as one stated, "On the asphalt, when you die, you lay there in your apartment and people don't even notice"), but complained that the favela was becoming increasingly inhospitable with an increase of violence and the disrespectful attitude of the younger generation.

Nevertheless the favela is often contrasted with the asfalto - in strong dichotomies of good and bad - while the health post can be described as a real heterotopia because it is a site of convergence for site and counter-site. The health post was always described to us as violencefree, although a big part of its raison d'être was based on treating patients directly or indirectly hurt through violent acts. The clean and friendly environment of the health post rendered it an exceptionally positive space for many of its clients. The women valued the respectful manner they were treated and were deeply attached to the posto: "At the Souza Aguiar hospital," said one woman, "they treated me like a dog. Here we are all equal. A family." And another woman: "Here ("remocei") I became 10 years younger. This is better than my family. The family only likes us when we have money. Without this here [the post], we are nothing. First Jesus, ${ }^{9}$ afterwards this here."

It is through the association with the health post and the psychosocial dynamics of the concept 'self-esteem' that the older women work on their citizenship, while both posto and self-esteem are tightly linked to their lives in the favela. The positive value given to self-esteem as a social factor that can be 'treated' through an originally psychological concept resembles the programs created by the State Assemblyman John Vasconcellos, who in the 1980s set up a task force on self-esteem in California. His argument was that "raising self-esteem in young people would reduce crime, teen pregnancy, drug abuse, school underachievement and pollution" (see Baumeister et al. 2005). In the case of the older women in our study, the complex interconnection of space, identity, and age can be translated, at least partly, into the language of hypertension.

\section{Hypertension, AGING AND PLACE}

Space is fundamental in any form of communal life; space is fundamental in any exercise of power. (Foucault 1984, 252)

The hypertension groups, alongside child health and pregnancy programs, were the main programs of the health post. The high profile of hypertension not only created something like a hypertension culture with its own language, slogans, and ideologies that was both incorporated and contested by the patients, it also showed the specificity of this favela as a hypertension-creating site.

The hypertension groups were organized almost like social clubs: one had access to a number of privileges after becoming a 'member' through referral by one of the doctors of the health post. If a patient was compliant (i.e. regularly attended the group sessions, took the medications as prescribed and sufficiently adapted one's diet to the doctor's recommendations), direct access to medical treatment was guaranteed and eliminated the need to wait in long lines in the early morning to receive clinical attention. Compliance was regularly measured after sessions by Dr Mariax, ${ }^{7}$ one of the three doctors working at the health post and who was responsible 
for the hypertension program: she was both feared as a controlling agent and gatekeeper and respected for her caring and sincerity. Leisure activities like bus excursions and parties were organized for the hypertension groups, while other afternoons were dedicated to health promotion activities, such as films followed by discussions; a number of conferences about blood pressure, aging and other health topics; and conscious-raising occupational therapy like the production of collages or paintings, some of which adorned the walls of the posto. Because of the importance given to self-esteem, group members were encouraged to attend the nearby State University of Rio de Janeiro, which had a Third Age University where some of the older women in the program learned how to read and write.

In 2010, the Brazilian Ministry of Health reported that $63 \%$ of the elderly suffer from hypertension (versus $24 \%$ of the adult population), with Rio de Janeiro leading the country's number of cases (Formenti 2010; Camarano 2002, 67). ${ }^{11}$ Although not exclusively found within the elderly, hypertension can be conceived as a disease of aging. This is because there is a common notion that in most environments, blood pressure - both systolic and diastolic - generally increases up to age $60,{ }^{12}$ which, after the National Institute of Aging (2010) is due to a number of risk factors of which only some (when they are lifestylerelated) can be targeted by public health campaigns. ${ }^{8}$

The intersection of the "spatial" with the "biological" is especially apparent in hypertension studies, which report a higher prevalence of hypertension in lower-income groups compared to higher-income groups (e.g. Grotto, Huerta and Sharabi 2008). And since people generally gather together in places which are indicative of their economic situation - although there are exceptions to this - hypertension (as obesity and several other illnesses which are highly context-dependent) can be transformed into maps mirroring the interaction between poorer neighbourhoods and cardiovascular health (see the maps published by the Brazilian Institute for Geography and Statistics [IBGE 2009] showing the distribution of Brazilian seniors and several health-related issues). The apparent simplicity of this correlation, that can become an ecological fallacy - is being disturbed by studies that found no clear geographical relation between socioeconomic factors and the distribution of hypertension. For the
Brazilian context, for example, a study by Campos et al. (2009) about seniors living in the medium-sized city Botucatu, in the state of São Paulo, shows that although the distribution of socioeconomic status and living area can be mapped as a direct correlation, the distribution of hypertension (and diabetes) could not. The authors think that the senior population in the city of Botucatu is much more homogeneous regarding lifestyle and ethnic origin than the socioeconomic differences seem to suggest.

The social sciences and the medical literature in the 1980s and 1990s, sometimes termed chronic health conditions such as hypertension as "diseases of civilization," linking them to specific ('industrialized') sites (e.g. Trowell and Burkitt 1981). James et al. (1991), for instance, noted that the Yanonami and other native Brazilian groups did not show the elevation of blood pressure with age found in many studies on industrialized places. And when these groups live in closer contact with more "mainstream" Brazilian culture, their mean blood pressure is significantly higher compared to those groups who live in more remote areas. This "native" phenomenon is a common finding in studies of indigenous groups around the world (e.g. Frohlich 1995; Rowe and Kahn 1998, 35f.). The explanation provided is generally a combination of genetic factors, diet (less salt and fat in native diets) and the common association of a less stressful life when compared to urban settings (e.g., Dressler 2004, Dressler et al. 1987, Kusuma et al. 2004, Steffens et al. 2006), which is of course a generalization that does not apply to all indigenous groups. ${ }^{14}$ While these risk factors certainly play a certain role in the wider phenomenon of hypertension, reducing them to civilization-blaming “...still exercises a strong Romantic hold", remarked Roy Porter $(1997,599)$. He suggests that one looks critically at any such claim, because

...with the spread of health education, with enlightened eating habits, ..., it appears likely that today's so-called diseases of civilization are not in any straightforward sense the products of affluence, but rather diseases disproportionately afflicting the less privileged members of advanced societies" (Porter 1997, 598; see also Roelcke 1999, esp. chapters 1 and 6; Littlewood 2002, 74-93).

Another recurring theme in hypertension studies is the connection between race, ethnicity (sometimes including racial genetics) and hypertension. For example, a number 
of studies show that African Americans have an earlier onset, a higher prevalence and more severe hypertension compared to non-Hispanic Whites (e.g., Kurdian and Cardarelli 2007). This generally accepted correlation is criticized by Thorpe Jr. et al. $(2008,1610)$ who conclude that the "socio-environmental context plays a substantial role in producing race disparities. ... Given similar socioeconomic status and similar socio-environmental conditions ethnic disparities in hypertension prevalence are substantially lessened." Thorpe Jr. et al.'s study raises the question whether a place like a favela, where a majority of its inhabitants has a darker skin, should be targeted by public health campaigns, when the target should not be the ethnic individual, but the stressful (in the widest sense) environment.

A further argument is related to the general increase of hypertension around the world. Some authors call attention to the fact that recent classificatory changes have lead to a more inclusive understanding of hypertension in direct relation to the marketing of hypertension drugs, such as Diuril (Lakoff 2007, Timmermann 2008). It is possible to imagine that due to changing inclusion criteria, new hypertension-related groups at risk can be detected and risk factors become more generalized, less specific. Different from the concrete example of the women's narratives located in a stressful favela (and validated by the health professionals), stress as a risk factor in biomedical reasoning is generalized ("a stressful life"), while intervention and prevention are dis-located and highly individualized: the American Heart Organization, for example, recommends that individuals become more joyful. ${ }^{15}$

\section{RISK TALK}

The regular hypertension group meetings were held in the afternoon. Once the small room with the wooden benches placed around the walls became available, group members entered and waited for the social worker or psychologist who would lead that particular session. This was the opportunity for informal chatting, gossip, and news. The women's conversation frequently steered to the risk factors of hypertension. The women discussed their food-related transgressions and compliances, (such as celebrations with their inevitable fatty and sweet dishes), the difficulties in maintaining a diet whereby one had to avoid cheaper and less nutritious food when money was never enough for the whole month, along with the violence on the hill.

Dona Elza: Sometimes I eat things that I am not allowed to, just because I have nothing else.

Dona Oneide: I eat everything because I have no shame (de sem-vergonhice). When there is, for instance, a wedding I eat everything I can. It's hard to resist.

Dona Teresa: She (Dr. Maria) told me that I can eat javali, wild pig meat - but where the hell do I find javali? ${ }^{16}$

Dietary restrictions are difficult - but not impossible - to follow, although most inhabitants of a favela have a limited income. However, the women who visit the posto do consider favelas are sites of violence that directly influence their well-being. ${ }^{17}$ As the following excerpt illustrates, the women's regular exposure to violence explains the impossibility of controlling hypertension, but also the significance of the health post where they, at least for a short period of time, participate in a non-violent world (no assault of the post has ever been reported).

Dona Elza: After 8 p.m., to leave the house - only with faith and following God... We live through our faith. This group gives a lot of support to our egos.

Social worker: Yes, to take the medication right is very important, but - [she points to the two sides of her head] - it's a lot of pressure, gente (folks)!

Dona Cecilia: And the police throw some drugs into your house, just to be mean..$^{18}$ One word of them is 20 times more valid than ours. One has to close the windows. They think that everybody here is the same [a bandit]. Policemen are liars.

Dona Teresa: [She tells us that her son was shot by the police or by a bandit that was dressed like a policeman, she was not sure]. Who to trust? There is no heart that can withstand all this. The bandits do not bother the inhabitants. (...) But the police. People are [their blood-] pressure. The nerves control the pressure, the heart beats.

Crime is only one of the many forms of violence, which cause suffering for these women. Gender issues, generational conflicts, and other family controversies are equally responsible for the stress ${ }^{19}$ they linked to hypertension. 
Dona Teresa: One lives oppressed inside the house. With my husband there is no dialogue. With him, everything is through fighting [na marra] ....While my husband was still working, we lived well. He arrived in the afternoon, drank a little and stayed the rest of the evening in bed [she imitates a drunkard]. Didn't bother anybody. Now it's different. He observes me all the time.

Violence has become a banal event, to a certain degree, among younger generations, and this aggravates the women's suffering, who perceive this generation gap as a sign of the noxiousness of the times they live in.

Dona Teresa: My granddaughter saw a child dying in the street and while grandma [herself] cried, granddaughter said that that was banal, 'Death is like that'. So my pressure was gone already. I pray to God. These young people are not afraid. I cannot lock my grandson in the house. He does not obey anymore.

Furthermore, the women perceived themselves as more vulnerable now than they were at younger age.

Dona Elza: After 40, we become more emotional, the older one gets, the more it is the emotional form of hypertension. The world became a violent world.

Before, there existed love, friendship.

The vulnerability of the aging body that provides less protection against a violent world, in the case of hypertension is being translated into a specific language of numerical relations.

\section{EMBODYING RISK AND HYPERTENSION: LIVING BY THE NUMBERS}

Although the women we worked with each had a different history, they identified themselves as 'hypertensives', creating a kind of biosociality (Rabinow 1996) that structured a great part of their life, in which the social and the biological were fundamentally intertwined. As 'hypertensives,' the women's entire lives were transformed into what Rayna Rapp (2000) calls "living by the numbers". Numbers helped articulate a great part of their identities and well-being. For instance, during the meetings, women frequently responded to greetings of "How are you" by scaling their degrees of hypertension with the degree of experienced violence: "Yesterday [after the shooting] I was 17:12, today I feel better, probably 14:10." In their everyday banter in the group, the degree of violence - whether domestic or on the hill - was directly related to the numbers indicating the degree of hypertension and for some, the higher the hill (where the poorer people lived), the higher the hypertension. The geographical attributes of the favela reflected the favela's built hierarchy as related to health. Accordingly, the physical and concrete materiality of the hill became central to our thinking early in our ethnographic research. At the beginning of the group sessions, we asked the participants to describe their social networks on the hill. Rather quickly, a pattern emerged with living areas located most high on the hill being related to the severity of one's hypertension. Generally speaking, poorer individuals lived high on the hill, while more well-off ones resided at the bottom. Violence is more accentuated higher on the hill, and the houses here, with their thinner walls, did not always offer suitable protection against the bullets, according to the women. "I think there are a few simple and exceptional examples in which the architectural means reproduce, with more or less emphasis, the social hierarchies," writes Foucault in Space, Knowledge, and Power (1984, 255).

The professionals at the health post made a similar link between violence close to their patient's living quarters and the degree of their hypertension. As Dr. Maria explained to us:

...There are many problems. A new cycle of violence has just started. Only last week we had ten deaths on the hill. And I can tell you, when they come afterwards to check their blood pressure, it is high - when I hear the shooting, I know already - they will come and their pressure will be terribly high. I hear the machine guns and in front of my eyes I see numbers [indicating the blood pressure]. It's war...

For Dr. Maria - as for the women - it was clear that hypertension is to a large degree a symptom, an idiom of distress linked to violence. The distress was felt, measured and categorized through the bodies of the women who lived that particular favela.

There were also numerical, interpersonal adjustments. For instance, the very fact of being an older individual was perceived as numerical: the older a person, the more vulnerable she was to the violent environment and everyday worries (the "emotional" form of hypertension). 
But being old also meant to have a certain power: for the older women, self-esteem as a means to citizenship had a specific currency. The women were very clear about the fact that money played a major role in their family relations. Since most elderly now receive a State pension (see e.g. Simões 2000), and because often younger family members were unemployed, the older individuals gain the status of the head of the family that they had lost due to their age in a country that values youth and the youthful body to a significant degree (e.g. Leibing 2001, Leibing and Collin 2013, Edmonds 2010).

As the excerpts above show, conversations revolved around two of the three main attitudes for a good hypertension management and the difficulty of avoiding certain foods and life's stress and strain when one is poor and lives in a violent environment. The third factor, hypertension medication, did not elicit much discussion. Because they were poor and part of the hypertension program, the women had free access to medications and therefore took them for granted. However, health professionals brought up issues of non-compliance by discussing how some women changed the dosages of their medicine according to their daily circumstances taking higher doses in response to negative life events or special occasions with forbidden food, and maintaining or reducing their dose when they perceived their life to be uneventful.

Furthermore, hypertension medications are "prescribed by numbers" (cf. Greene 2007) - that is, prescribed by diagnosing illness on the basis of numerical deviations from a norm established by more or less neutral experts and now often treated on a preventive basis before any sign of illness has developed. At the same time, patients were self-dosing by numbers: since the dose of medication and severity of hypertension can both be measured and related to each other, the language of numbers and its apparent objectivity is self-evident. ${ }^{20}$

Another medication group, tranquilizers, were prescribed to one third of the women. Dr. Maria was aware of the profoundly troubling environment of the favela, but this did not translate to possible treatment options:

Dr Maria: So there is the medication. They have to take care of what they eat; and self-esteem is also an important point. (...) Here, there is a lot of stress, what can one do? I try to give as few tranquilizers as possible. It is wrong to prescribe them to these people, but I often have no choice. It's either that or nothing. It is like [artificially] transforming the lion into a little mouse. And the groups help. The groups work like a valve and there is a lot of solidarity. The high stress level of modern life brings with it all these diseases. Stress is the biggest problem.

To a certain degree, treatments and the discourse of risk also undergird the need for more nuanced understanding regarding the medicalization of poverty. Borrowing the words of Nikolas Rose (2007): medicalization is not simply a "recoding of misery," but involves "delicate affiliations" between complex matters such as the politics of identity and the moral economics of inclusion. Dr Maria's statement that " $[t]$ hese women have always been treated badly by the public health system. I try to really look at them, to touch them - that's important" demonstrates her awareness of her role in acknowledging the citizenship of individuals who, for a long time, were invisible in public discourse unless they were depicted in extreme or stereotyped manners: on the one hand, part of the violent image of a favela, the criminals with their negative media, or, on the other hand, part of the positive favela of famous samba dancers or singers or, close to the elections, as voters.

\section{THE MOUSE AND THE LION}

Place is not always significant when talking about health and illness (although all practices related to health happen somewhere), yet I suggest that there are some forms of suffering which reveal the interconnectedness of place, the (aging) body, identity, and power, and may be understood as heterotopic illness. ${ }^{21} \mathrm{I}$ focus on counter-sites - taking Michel Foucault's reflections regarding heterotopias as an inspiration - because these spaces generally create tensions by by inverting what is taken for granted - something that is felt most acute by those who suffer from place-related distress. The concept of heterotopic illness helps to pose questions, which challenge one to go beyond too easy recipes of self-care.

Heterotopic illnesses, in this specific context, is critical of health promotion activities which reinforce the moral economy of neoliberal thinking by valorizing self-care. When illness is linked to place, hypertension is no longer 
an illness/disease that can be centred on the individual. Accordingly, the hypertensive bodies of the older women discussed in this article form the basis for articulating a citizenship based on a place-linked identity - a mix of the favelado, the hypertensive, and the old as shared by all of them.

Nevertheless, Dr Maria continues to prescribe tranquilizers, and the question of how exactly the "lion can be transformed into a mouse" remains unanswered. While the concept of heterotopic illness does not prevent the practice of medicating social problems; it does help us better understand how using mouse-traps (here meaning all interventions ignoring heterotopias) - while useful for catching mice - are an inadequate solution for fighting the lion.

\section{Notes}

1. Like Foucault, I am using space, site, and place interchangeably in this paper, since in most cases it does not make sense to separate phenomenology and dimensions of place/space from each other. Many theoreticians distinguish among them. For example, Michel de Certeau defines space as the product of action and movement, while place implies stability (cf. Reynolds and Fitzpatrick 1999). Others define space as linked to the question of dimensions, while place is the lived space (e.g. Low 1996).

2. Heterotopia was first mentioned by Foucault in The Order of Things (1966). He rethought heterotopia in 1967, when he gave a lecture called "Des espaces d'autres" at the Cercle d'études architecturales in Paris. His discussion of heterotopia drew greater attention in English-language scholarship two years after his death in 1986, when his 1967 conference under the title of "Other Spaces" was published in the United States (Sohn 2008, Foucault 2005, Chlada 2005, 7-14). I have elsewhere applied the six principles through which Foucault analysed a heterotopia to a Brazilian favela (Leibing 2010). Because of the limited space of this article, I will just name them here: 1) heterotopias may be either based on crises or deviance; 2) the function of a heterotopia may change over time; 3 ) several spaces may be juxtaposed in a single heterotopia; 4) heterotopias are linked to 'slices of time'; 5) heterotopias have systems of opening and closing; and 6) they function in relation to all remaining space. See also the critiques regarding heterotopias made by Lefebvre (1991, 3-4) and Giddens (1984, 145-161); see also Philo (2000).

3.Exclusion does not always have a negative connotation; it can be desired as in the case of exclusive spa sites or a university (comparable to Goffman's [1963] 'positive stigma'). As well, heterotopias are not necessarily spaces with a negative impact on individuals (as the most perfect heterotopia Foucault mentioned a ship), and such places can protect and enhance the well-being of its inhabitants or just have a neutral effect on people's health.

4.My reading of the text on heterotopia stems from Foucault (2005). For the quotes (the English translation) I used http:// foucault.info/documents/heteroTopia/foucault.heteroTopia.en.html

5. We tried to find out about this curious fact. It seemed that the older women strongly stigmatized people who showed the symptoms of dementia. At the time of fieldwork two famous members of the community were suffering from dementia (it had been reported in the media), and by using these concrete examples it became clear that the symptoms were associated with unpredictability and madness, and some of the women strongly condemned the antisocial behavior of these individuals. The health professionals thought that there might be some older individuals on the hill who suffered from a dementia. However, they did not see those patients and did not know what happened to them. Their central health concern when treating their older clientele was hypertension.

6. There are many studies that link violence to hypertension (see, for instance the American Institute of Stress http://www. stress.org/) that I am unable to address here.

7. This notion dates back at least to the Bohemian journalist João do Rio (1881-1921).

8. A certain paradox exists, since the carnival is produced by «favelados », but the key roles are increasingly taken by starlets and mannequins. The authenticity stemming from popular culture rooted in a low-income community has been questioned by many since the official carnival has been rigidly pressed into the sambodromo, an open space made of concrete and separated from the public, and has become an investment that a poor community could never produce without sponsors (who, for many years, have been the powerful bosses of the illegal "animal lottery"; see Cavalcanti 2006).

9. The majority of the women we saw in these groups were Catholic. Although the new evangelic churches are now dominating low-income communities in Brazil (Arias 2004), many older individuals seem to stay committed to the Catholic church. The women's participation in Afro-Brazilian religions, such as Umbanda, was not discussed in the group sessions, although we did broach the subject.

10. All names used in this article are pseudonyms.

11. For the State of São Paulo Zaitune et al. $(2006,285)$ conclude: "Hypertension prevalence [in the elderly] was 51.8\% (46.4\% in men and $55.9 \%$ in women) and was higher among the elderly with less education (55.9\%), immigrants from other States $(60.2 \%)$, and the overweight or obese $(57.2 \%)$ ".

12. After age 60 , the systolic pressure might still increase, but diastolic pressure tends to stabilize or decrease 
13. The NIH (National Institute of Health 2010) lists the following risk factors associated with hypertension: 1 . older age; 2 . race/ethnicity; 3 . overweight or obesity; 4 . unhealthy lifestyle habits (salt, alcohol, not enough physical activity, smoking...); and 5. other risk factors (such as family history, long-lasting stress, and so on.).

14. Although limited to a journal with a specific scopePsychosomatic Medicine - Engel (1998) showed that all articles that appeared on blood pressure between 1939 and 1997 talk about hypertension as reactive to the environment in which a person lives. We are not able to outline here or even mention all discussions regarding risk factors for hypertension, such as physical activity or geneticenvironment interactions. See also Sapolsky (1992), who relates stress (and hierarchy) to the aging brain.

\section{5. (see http://www.heart.org/HEARTORG/Conditions/} HighBloodPressure/Prevention\%20TreatmentofHighBloodPressure/ Stress-and-Blood-Pressure UCM_301883 Article.jsp). Conceptualizing hypertension as a heterotopic illness can resemble what some authors have called 'structural violence'. Many people living in low-income neighbourhoods such as the favela clearly suffer from what Farmer, Nizeye, and Keshavjee (2006, e449; emphasis in the original) explain as "arrangements [which] are structural because they are embedded in the political and economic organization of our social world; they are violent because they cause injury to people (typically, not those responsible for perpetuating such inequalities)." Heterotopic illness is not necessarily associated with victims. Good and bad, victim and masters, here and there are not predefined, but mingle and overlap. This way of perceiving social relations as related to counter-sites can avoid what Loïc Wacquant (2002) rightly condemns as "moralism" in some studies on low-income communities.

16. Dr Maria denied that she had recommended wild pig meat, but perhaps she had mentioned it as an example of a lower fat meat when compared to commercial pork. However, the example of 'javali' was well remembered by the group and was repeatedly referred to, becoming the symbol of the impossibility of respecting the nutritional prohibitions.

17. Anthropologist Cornelia Eckert (2002) shows how older women in Porto Alegre link their life histories to the city, and how violence and chaos influence the way the women's autobiographies are constructed.

18. The negative image of the police cannot be deepened here (see Leibing 2001), but many studies have shown this (e.g. Gonçalves 2000, Antunes, Conti and Marqueiro 2000).

19. We adopt here the common meaning of stress to refer to any stressor that affects an individual's well-being. For a critical history of stress see, for instance, Viner (1999).

20. See Greene 2007: chapters 1 and 2 on hypertension medications as a 'therapeutic embrace'.
21. Although Foucault did not make an explicit link between heterotopias and health he must have known the medical term "heterotopia", which indicates the displacement of an organ or cells from normal positioning in the body (see Sohn 2008).

22. Brazilian social epidemiologist Cecilia Minayo $(2006,380)$ observes: "The greatest difficulty lies in convincing a sector deeply marked by biomedical reasoning to accept in its model and dynamics complex problems of social character and not diseases. Many times I ask myself: 'Does one die more when dying from AIDS or cancer than when dying from a traffic accident or murder?"”

\section{REFERENCES}

\section{Anderson, Elizabeth}

2010 The Imperative of Integration. New Jersey: Princeton University Press.

Antunes, L, Conti, L and P Marqueiro

2000 A estatistica do medo; Pesquisa mostra que maioria no Grande Rio ja foi assaltado e desconfia da policia. O Globo 18 06.2000: 16.

Arias, Enrique Desmond

2004 Faith in our neighbors: networks and social order in three Brazilian favelas. Latin American Politics \& Society 46(1): 1-38.

Bachelard, G.

1994[1958] The Poetics of Space. Boston: Beacon Press.

Barke, M., Escanasy T and G. O'Hare

2001 Samba: A Metaphor for Rio's Favelas? Cities 18(4): 259270.

Bauermeister, RF, Campbell, JD, Krueger, JI, and KD Vohs

2005 Exploding the Self-Esteem Myth. Scientific American Mind, December 2005 online issue, accessed May 2013.

Beck, Ulrich

2007 Beyond class and nation: Reframing social inequalities in a globalizing world. The British J Sociology 58(4): 679-705.

Bhaba, $\mathrm{H}$.

1994 The Location of Culture. London/New York: Routledge. Campos, Frederico G. et al.

2009 Distribuição espacial dos idosos de um município de médio porte do interior paulista segundo algumas características sócio-demográficas e de morbidade. Cadernos Saúde Publica 25(1): online version (accessed January 2013). 
Cavalcanti, MLVC

2006 O Rito e o Tempo: Ensaios sobre o Carnaval. Rio de Janeiro: Civilização Brasileira. 3rd ed.

Chlada, Marvin

2005 Heterotopie und Erfahrung, Abriss der Heterotopologie nach Michel Foucault. Aschaffenburg: Alibri.

Dressler, W.W.

2004 Culture and the risk of disease. Br Med Bull 69(1): 21-31.

Dressler, W.W. et al.

1987 Arterial Blood Pressure and Modernization in Brazil. American Anthropologist 89(2): 398-409.

Duarte, Luiz Fernando D.

1986 Da Vida Nervosa nas Classes Trabalhadores Urbanas. Rio de Janeiro: Zahar.

Eckert, Cornelia

2002 A Cultura do Medo e as Tensões do Viver a Cidade: Narrativa e trajetória de velhos moradores de Porto Alegre. In: Antropologia, Saúde e Envelhecimento. C Minayo and CEA Coimbra (eds.). Rio de Janeiro: Fiocruz.

Edmonds, AE

2010 Pretty Modern: Beauty, Sex and Plastic Surgery in Brazil. Durham, NC: Duke University Press.

Eisenberg, Leon

2004 Social psychiatry and the human genome: contextualising heritability. The British Journal of Psychiatry 184: 101-103.

Elden, $\mathrm{S}$.

2001 Mapping the Present: Heidegger, Foucault and the project of a spatial history. London: Continuum.

Farmer PE, Nizeye B, Stulac S, Keshavjee S

2006 Structural Violence and Clinical Medicine. PLoS Med 3(10): e449. doi:10.1371/journal.pmed.0030449.

Fonseca, Pedro

2007 Em favela no Rio, Lula promete "cidadania" com PAC. Reuters Brasil http://br.reuters.com/article/topNews/ idBRN3029396220071130 (accessed October 2010).

Formenti, Lidia

2010 Quase 25\% da população brasileira sofre de hipertensão, aponta pesquisa, Prevalência da doença aumentou em todas as faixas etárias, principalmente entre os idosos. Estado de São Paulo 26 April, 2010, online http://www.estadao.com.br/noticias/ vidae,quase-25-da-populacao-brasileira-sofre-de-hipertensaoaponta-pesquisa, 543186,0.htm, accessed August 2010.
Foucault, Michel

2005 Die Heterotopien, Der utopische Körper. Bilingual edition (French and German). Translation Michael Bischoff. Frankfurt: Suhrkamp.

Gibson-Graham, J K

2006 A Postcapitalist Politics. London: University of Minnesota Press.

Goffman, Erving

1963 Stigma: Notes on the Management of Spoiled Identity. New Jersey: Prentice Hall.

Gonçalves, Liane

2000 Policiais a serviço do crime. O Globo 02 June 2000, p. 18.

Grotto I, Huerta M, and Y. Sharabi

2008 Hypertension and socioeconomic status. Curr Opin Cardiol. 23(4): 335-339.

Greene, Jeremy A.

2007 Prescribing by Numbers: Drugs and the definition of disease. Baltimore: The Johns Hopkins University Press.

Hanrahan, Mark

2013 Slum Tourism: Shanty Town Tours In Brazil, India, South Africa Give Travelers Glimpse At Poverty; Raise Ethical Questions. The Huffington Post 05.02.2013, online http://www. huffingtonpost.com/2013/05/08/slum-tourism-brazil-india-southafrica n_ 3237489.html.

Harris, Edmund

2009 Neoliberal subjectivities or a politics of the possible? Reading for difference in alternative food networks. Area 41(1): 55-63.

Hetherington, Kevin

1997 The Badlands of Modernity: Heterotopia and Social Ordering. Routledge.

Huguet, Clarissa and Ilona Szabo de Carvalho

2008 Violence in the Brazilian favelas and the role of the police. New Directions for Youth Development 119: 93-109.

IBGE (Instituto Brasileiro de Geografia e Estatística)

2009 http://www.ibge.gov.br/english/estatistica/populacao/indic sociosaude/ 2009/indicsaude.pdf, accessed March 2013.

James, S. et al.

1991 Hypertension in Brazil: A Review of the Epidemiological Evidence. Ethnicity \& Disease 1, Winter 1991: 91-98.

Kurdian, AK and KM Cardarelli

2007 Racial and ethnic differences in cardiovascular disease risk factors: a systematic review. Ethn Dis. 17(1): 143-152. 
Kusuma YS, Babu BV, Naidu JM

2004 Prevalence of hypertension in some cross-cultural populations of Visakhapatnam district, South India. Ethn Dis 14(2): 250-259.

Leibing, Annette

2001 Marcinho et Mauricinho, Violence et les nouveaux héros de Rio de Janeiro, Brésil. Anthropologie et Sociétés 25(3): 5168, 2001.

2002 Flexible Hips? On Alzheimer's disease and aging in Brazil. Journal of Cross-Cultural Gerontology 17(3): 213-232.

2009 Tense prescriptions? Alzheimer medications and the anthropology of uncertainty. Transcultural Psychiatry 46(1): 180-206.

2010 Inverting compliance, increasing concerns: Aging, mental health, and caring for a trustful patient. Anthropology \& Medicine 17(2): 145-158.

Leibing, A. and J. Collin

2013 The multiple anxieties of getting older: A comparative study of tranquilizers and the ambivalence of effect. Medical Anthropology 5(1): 399-416.

Littlewood, Roland

2002 Pathologies of the West, An anthropology of mental illness in Europe and America. Ithaca: Cornell University Press.

Low, Setha

1996 Spatializing Culture: The Social Production and Social Construction of Public Space. American Ethnologist 23(4): 861-879.

Magalhães, Luiz Ernesto

2009 Rio 2016: Lula diz que crescimento da economia pode transformar favelas em bairros em até 10 anos. O Globo 03.10.2009, online issue http://oglobo.globo.com/rio/rio2016/ mat/2009/10/03/rio-2016-lula-diz-que-crescimento-da-economiapode-transformar-favelas-em-bairros-em-ate-10-anos-767898632. asp, accessed October 2010.

Minayo Maria Cecília de Souza

2006 The inclusion of violence in the health agenda: Historical trajectory.Ciência \& Saúde Coletiva 11(2): 375-383.

$\mathrm{NIH}$ (National Institute of Health)

2010 Who is at risk for high blood pressure? http://www.nhlbi. nih.gov/health/health-topics/topics/hbp/atrisk.html (accessed May 2010)

Porter, R.

2001 Diseases of civilization, see http://dahsm.medschool.ucsf. edu/history/DiseasePDF/10 Roy_Porter.pdf (accessed January 2012).
Porto, Maria Stela Grossi

2000 A violência entre a inclusão e a exclusão social. Tempo Social 12(1): 187-200.

Prefeitura da Cidade do Rio de Janeiro

2006 Favelas Cariocas. Online document http://www. armazemdedados.rio.rj.gov.br/arquivos/1761 restudos $\% 20233 \% 20$ favelas $\% 20$ cariocas $\% 20$ compara $\% \mathrm{C} 3 \% \mathrm{~A} 7 \% \mathrm{C} 3 \% \mathrm{~A} 30 \% 20 \mathrm{de} \% 20$ \%C3\%A1reas\%20ocupadas.PDF; accessed August 2010.

Rabinow, Paul

1996 Essays on the Anthropology of Reason. Princeton University Press.

Rapp, Rayna

2000 Testing Women, Testing the Fetus - The social impact of amniocentesis in America. New York: Routledge.

Reynolds, Bryan and Joseph Fitzpatrick

1999 The Transversality of Michel de Certeau: Foucault's Panoptic Discourse and the Cartographic Impulse. Diacritics 29(3): 63-80.

RioOnWatch

2010 http://rioonwatch.org/?p=5931, accessed May 2012.

\section{Roelcke, Volker}

1999 Krankheit und Kulturkritik, Psychiatriche Gesellschaftsdeutungen im bürgerlichen Zeitalter (17901914). Frankfurt/M: Campus.

Romer, Simon

2013 Public Rapes Outrage Brazil, Testing Ideas of Image and Class. New York Times online edition http://www.nytimes. com/2013/05/25/world/americas/rapes-in-brazil-spur-class-andgender-debate.html?ref=brazil (May 24, 2013).

Rose, Nikolas

2007 Beyond medicalisation. The Lancet 369(February 24): 700-702.

Sapolsky, Robert M.

1992 Stress, the Aging Brain, and the Mechanisms of Neuron Death. Cambridge, MA: The MIT Press.

Schiller, Jakob

2013 Banishing Drug Lords From Rio de Janeiro's Favelas in Pre-Olympic Sweep; see http://www.wired.com/rawfile/2013/02/ rafael-fabres-favelas/

Segre, Roberto

2008 Rio de Janeiro, Brazil: The articulation between formal and informal city. In: K. Moraes and A. Guney (eds.). Understanding meaningful environments, Architectural precedents and the question of identity in creative design. Amsterdam: IOS Press. 
Simões, Julio A.

2000 Solidariedade em xeque: as mudanças na seguridade social e o movimento de aposentados e pensionistas no Brasil. In: G. G. Debert and D. M. Goldstein. (eds.). Políticas do corpo e o curso da vida. São Paulo: Editora Sumaré, 2000, pp. 267-285.

Sohn, Heidi

2008 Heterotopia: Anamnesis of a medical term. In: Heterotopia and the City, Public Space in a Postcivil Society. Michel Dihiene and Lieven De Cauter, eds. Abingdon: Routledge, pp. 41-50.

Sophia, Ace

2008 Foucault's Heterotopias: The "Other" Spaces between what is Real and Utopian. Philosophy (Feb 13): 1-5.

Steffens, Patrick R., et al.

2006 Acculturation to Western Society as a Risk Factor for High Blood Pressure: A Meta-Analytic Review. Psychosomatic Medicine 68: 386-397.

Thorpe, Jr. Roland J., Dwayne T. Brandon, and Thomas A. LaVeist

2008 Social context as an explanation for race disparities in hypertension: Findings from the Exploring Health Disparities in Integrated Communities (EHDIC) Study. Social Science and Medicine 67: 1604-1611.

Timmermann, Carsten

2008 How does a Drug become Medicine? Hexamethonium and the Treatment of High Blood Pressure, 1940s-1950s. In Gaudilliere JP and V. Hess (eds.), Ways of Regulating. Berlin: MPIWG, pp. 153-163.

Toennies, Ferdinand

1963 [1887] Community and Society (Gemeinschaft und Gesellschaft). Translated and edited by Charles P. Looomis. New York: Harper \& Row.

Trowell, $\mathrm{H}$ and D Burkitt

1981 Blood-pressure rise with age - a Western disease? Lancet Sep 26; 2(8248): 693-694.

Valladares, Licia P.

2000 A gênese da favela carioca. A produção anterior às ciências sociais. Rev. bras. Ci. Soc. [online] 15(44): 05-34.

2003 Pensando as Favelas do Rio de Janeiro, 1906-2000. Rio de Janeiro: Urban Data Brasil.

2005 A Invenção da Favela. Do mito de origem à favela.com. Rio de Janeiro: Editora FGV.
2006 La favela d'un siècle à l'autre: Mythe d'origine discours scientifiques et représentations virtuelles. Paris: Maison des sciences des hommes.

Valladares, Licia P. and Medeiros, Lídia (eds.).

2003 Pensando as Favelas do Rio de Janeiro, 1906-2000: Uma bibliografia analítica. Rio de Janeiro: Relume Dumará: Faperj: Urbandata, 2003.

Ventura, Zuenir

1994 Cidade Partida. Rio de Janeiro: Companhia das Letras.

Viner, Russell

1999 Putting Stress in Life: Hans Selye and the making of stress theory. Social Studies of Science 29(3): 391-410.

Wacquant, Loïc

2002 Review Symposium, Scrutinizing the Street: Poverty, Morality, and the Pitfalls of Urban Ethnography. American Journal of Sociology 107(6): 1468-1532.

Wiles, Janine, Leibing, Annette, Guberman, Nancy, Reeve, Jeanne, and Ruth Allen

2012 The meaning of 'ageing in place' to older people. The Gerontologist 52(3): 357-366.

Williams, Allison

1999 Therapeutic landscapes: The dynamic between place and wellness. Lanham: University Press of America.

Zaitune, Maria Paula do Amaral, Barros, Marilisa Berti de Azevedo, César, Chester Luiz Galvão, Carandina, Luana and Moisés Goldbaum

2006 Hipertensão arterial em idosos: Prevalência, fatores associados e práticas de controle no Município de Campinas, São Paulo, Brasil. Caderno Saúde Pública 22(2): 285-294.

Zaluar, Alba and Marcos Alvito (eds.)

2005 Um século de favela. Rio de Janeiro: Editora FGV, 5th ed. 